\title{
Distribution and Threats of Rufous-Necked Hornbill (Acerosnipalensis) in Bhutan
}

\author{
Tej Kumar Nepal \\ Student, Master of Ecology and Environment Studies, School of Ecology and Environment Studies, Nalanda University, Rajgir, Bihar, India \\ Email: tejkumarnepal97[at]gmail.com
}

\begin{abstract}
Hornbills (Bucerolidae) have a huge bill with a casque on upper mandible in some species. The casque is smaller in female in some species. Rufous-necked Hornbill (Acerosnipalensis), which belongs to Bucerolidae family, is a big bird measuring 90-100 cm long, with around $150 \mathrm{~cm}$ wingspan and weighing somewhat between 2 and $4 \mathrm{~kg}(4.4 \mathrm{to} 8.8 \mathrm{lb})$. They are found in the Indian Subcontinent, East Asia and Southeast Asia. It is listed as Vulnerable in IUCN Red List, Appendix II of CITES and Schedule I (totally protected wild animals) species in Forest and Nature Conservation Act of Bhutan, 1995. It has high forest dependency and is mostly found between the altitude of 150 and 2,200 meters. Rufous-necked Hornbill mostly feeds on berries, drupes, fruits of Lauraceae spp., Moraceae spp., Annonaceae spp. and Meliaceae spp. In Bhutan, Rufous-necked Hornbill is reported from Samtse, Chhukha, Trashigang, Zhemgang, Monggar, SamdrupJongkhar, Sarpang Districts, along PunatshangChhu, and mostly from Wildlife Sanctuaries and National Parks. Though being vulnerable in nature and ecologically important species, it is poorly studied and documented in Bhutan. Therefore, this paper aimed to review published secondary sources related to Rufous-necked Hornbill in Bhutan. The result showed that there were no illegal killings of species in Bhutan. Habitats are threatened because of timber extraction, road construction, clearing of forest for power transmission lines and dying of nest trees.
\end{abstract}

Keywords: Bucerotidae; Habitat loss; Vulnerable; Hotspot, Hornbill, fragmentation, fruits

\section{Introduction}

Bhutan, with an area of $38,394 \mathrm{~km}^{2}$ (DoFPS, 2018), a country rich in biological diversity is sandwiched between two super powers, China in North and India in South, East and West(NBSAP, 2014). Bhutan lies to the East of Himalaya with a total of 11,248 species within all biodiversity taxa (NBC, 2019).Bhutan is a part of 8 ecoregions, 23 important bird areas, important plant areas and wetlands with 3 Ramsar sites (Banerjee \& Bandopadhyay, 2016). Bird diversity of Bhutan is the reflection of country's unique geographical position, altitudinal variation and climatic differences. Till date, 752 species (26 globally threatened) of birds have been recorded for Bhutan (NBC, 2019), of which southern and central part of the country embodies the highest avian diversity. Of the 54 species of Hornbills (Jinamoy 2013; Sadadev, Dhami, Thapa, Bista, Rawat, Neupane and Gautam 2020),Asia harbors 33 species of hornbill (Poonswad, Kemp, \& Strange, 2013).Oriental Pied hornbill (Anthracocerosalbirostris), Rufous-necked Hornbill (Acerosnipalensis), Wreathed Hornbill (Rhyticeros undulates) and Great Hornbill (Bucerosbicornis) are the 4 species of Asian hornbills found in Bhutan (Grimmett, Inskipp, Inskipp, \& Sherub, 2019). Oriental Pied Hornbill is listed as Least Concern globally, while the other three are Vulnerable (Sherub \& Singh, 2020). Globally, Rufous-necked Hornbill (Acerosnipalensis) is listed as Vulnerable by International Union for Conservation of Nature (Shukla, Naniwadekar, \& Datta, 2016), listed as protected species under Schedule I of the Forest and Nature Conservation Act 1995 of Bhutan (RGoB, 1995) and listed in Appendix II by Convention on International Trade in Endangered Species of Wild Fauna and Flora (CITIES)(Sadadev, et al., 2020). Similarly, Forest and Nature Conservation Rules and Regulations, 2017 kept them under Schedule-I (protected) species with heavy fines and penalties for defaulters (UWICER, 2017). Its population is declining across much of its global range(Shukla et al, 2016). Rufous-necked Hornbill is reported from evergreen forest in Bhutan, Northern Myanmar, Western and Northern Thailand, part of North Eastern India, Southern China, Northern Laos and North-western Vietnam(Sherub \& Singh, 2020). It is close to extinction in Vietnam and reportedly extinct from Nepal (Poonswad et al, 2013). Globally, its population is estimated to be around more than 2,500 but less than 10,000 birds(Poonswad et al, 2013).

Rufous-necked Hornbill feed on the fruits of 33 plants (Appendix 1), invertebrate species including bee larvae, freshwater crabs, young of birds, caterpillars, and beetles (Appendix 2) (Sherub \& Singh, 2020). Breeding season begins from the last week of April and last till August, approximatelyabout 4 months (Shukla, Naniwadekar, \& Datta, 2016). Rufous-necked Hornbills are recognized to range over large space (Datta \& Rawat, 2003). Their presence indicates the good health of the forest as they require large tracts of primary forest with large trees for nesting (Poonswad \& Kemp, 1993) and plays an important functional role as seed dispensers (Kannan \& James, 1999).Despite having significant role in the ecosystem, this species is threatened by habitat loss and fragmentation, grazing, extraction of timber, and cutting of fruiting trees (Mudappa \& Raman, 2009). Though they are not at risk of extinction in Bhutan, but they are facing the impact of economic development and globalization (Sherub \& Tshering, 2019).

The study aimed to study the distribution evidences and threats of Rufous-necked Hornbill from the published papers in and out of Bhutan. There were not many published paper of Rufous-necked Hornbill based on Bhutan, but some paper published by non-Bhutanese had mentioned about the threats and distribution of Rufous-necked Hornbill in Bhutan.

Volume 9 Issue 11, November 2020

www.ijsr.net

Licensed Under Creative Commons Attribution CC BY 


\section{Methods and Materials}

This paper was set up by checking the relevant published papers globally and nationally on Rufous-necked Hornbill (Acerosnipalensis) from late 1990s till 2020. The distribution of the species was also extracted from eBird (www.ebird.org), iNaturalist (www.inaturalist.org) and Bhutan Biodiversity Portal (www.biodiversity.bt), an online citizen science project. The literature mostly focused on ecology, status and threats of Rufous-necked Hornbill.There was more study conducted on this species from 2010. I found only few papers with threat assessment and population density estimates. Therefore, numerous papers published were used to extract information and mold the information into consumable one. Gathered information was utilized well and the authors are cited accordingly.

\section{Results and Discussions}

\subsection{Status and Distribution}

In Bhutan, Rufous-necked Hornbill is distributed at the altitude of 150-2,200 $\mathrm{m}$ in mature broadleaf forests (Inskipp, Inskipp, \& Grimmett, 1999).The Rufous-necked Hornbill is sighted at SamdrupJongkhar, Trashigang, Monggar, PemaGatshel, Zhemgang, Gelephu, Trongsa, WangduePhodrang, Punakha, Samtse and Chhukha(eBird, 2020; BBP, 2020; iNaturalist, 2020).JigmeDorji National Park, Phibsoo Wildlife Sanctuary, JigmeSingyeWangchuck National Park, Royal Manas National Park and Jomotsangkha Wildlife Sanctuary reported the sightings of the Rufous-necked Hornbill (BBP, 2020; eBird, 2020; iNaturalist, 2020). Rufous-necked Hornbill is occasionally sighted from other places as well but they are not documented well (UWICER, 2017).

\section{Major Threats}

The anthropogenic activities pose threats to the habitat and survival to the world's most distinct bird species(Pandit \& Grumbine, 2012). The Rufous-necked Hornbill is mainly threatened by deforestation, mortality due to natural calamities and food resource competition.

\section{Deforestation}

Hornbills are greatly affected when the fruiting trees are felled down for extension of roads, power transmission towers, construction of farm roads and illegal logging (Thongsikem, Poonswad, \& Kemp, 2014). Moreover, the collection of non-wood forest product (NWFP), fodder for cattle and handicrafts development poses greater threats to Hornbills in Bhutan (UWICER, 2017). The subsidized timber resources provided by the National Policy encourage people to use more trees for firewood and construction proposes (Datta, 2009).

\section{Mortality due to natural calamities}

There are many other factors threatening the habitat and survival of Rufous-necked Hornbill, apart from anthropogenic pressure (Datta, 1998). Landslides during the summer, disease out breaks, accidental forest fires, famines and conditions of the nesting trees are some of the evident catastrophes threatening the life of Hornbills in Bhutan (Dorji, 2013).

\section{Food resource competition}

Though their role as seed dispersers are ecologically important, all the seeds dispersedwill not generate 100 percent as it depends on various factors such as seed viability, ground substrata, and climatic elements (UWICER, 2017). The age old practice of cattle herding by communities poses threats to Hornbills and reduces food sources as they collect cattle fodder, wild foods for home consumption and commercial purposes, trees felled for handicraft making, NWFP as traditional medicines is considered as better than scientific medicine in Bhutan(Pandit, Manish, \& Koh, 2014).

Bhutan has not documented or reported poaching and hunting against Rufous-necked Hornbill although their beaks kept as trophies are found in rural households (UWICER, 2017).Creating employment opportunities from ecotourism through Hornbill conservation, sustainable forest management, alleviation of poverty(Banerjee \& Duflo, 2011), and conservation for education and recreational purposes are some of the benefits of presence of Hornbill in residential community(Poonswad P. , 1998).

\section{Conservation Measures}

The Constitution of the Royal Kingdom of Bhutan mandates to keep 60 percent forest cover for all times to come(Tobgay, 2015). The national developmental philosophy of Gross National Happiness (GNH) places Conservation of Environment as one of the four pillars(Tella \& MacCulloch, 2008).The National Assembly of Bhutan passed the Forest and Nature Conservation Act of Bhutan 1995, where Rufous-necked Hornbill was classified as Schedule I species (totally protected), along with other critically important species(RGoB, 1995). The Forest and Nature Conservation Rules and Regulations, 2017 further made their conservation strong by introducingheavy fines and penalties for defaulters(UWICER, 2017). The forest cover of 71 percent (DoFPS, 2018) is great home for Rufous-necked Hornbill, but will their conservation be as strong as now in near future.

\section{Conclusion}

While collecting and the reviewing the scholarly works on Rufous-necked Hornbill thoroughly, I found out that there was not a single paper writing about the poaching and hunting of the species in context of Bhutan. Human-induced interventions such as deforestation, habitat loss and fragmentation, and developmental activities are effecting the population and habitat of Rufous-necked Hornbill. Forest and Nature Conservation Act of Bhutan 1995 and Forest and Nature Conservation Rules and Regulations 2017 kept them under Schedule-I (totally protected) species, but detailed research on its documentation of status, distribution, threats and behavioral ecology of this species is needed. Insufficient data poses major drawback to the management and conservation efforts. Hence, detailed ground level collective evidences on population density, breeding biology, threats, distribution, behavioral ecology and diet composition should be studied to aid in the conserving and maintaining the viable population of Rufous-necked Hornbill. 


\section{Way Forward}

Separate Hornbill Protection and Management Plan must be incorporated for specificaction to conserve and manage the population of Rufous-necked Hornbill and its habitat. Detailed ground level collective evidences on population density, breeding biology, threats, distribution, behavioral ecology and diet composition should be studied to aid in the conserving and maintaining the healthy population of Rufous-necked Hornbill. Conservation awareness programs for the public and inclusion of importance of Hornbills (and other birds) in syllabus in schools' and colleges' education are vital in making people aware about its vulnerable state. People should also be made aware of the law protecting the ecologically important species and to keep people away from practicing illegal killing. The effect of climate change on Hornbill's habitat and food habit should be studied to aid in conservation of the species. Carrying timely research on Hornbill population is important to determine the impact of economic development and to check their resilient capacity to adapt to the changing climate.

\section{References}

[1] Banerjee, A., \& Bandopadhyay, R. (2016). Biodiversity Hotspot of Bhutan and its Sustainability. Current Science, 110(4), 521-527.

[2] Banerjee, A., \& Duflo, E. (2011). Poor Economics. New York: PublicAffairs.

[3] BBP. (2020). Rufous-necked Hornbill. Retrieved 2020, from Bhutan Biodiversity Portal: www.biodiversity.bt

[4] Datta, A. (1998). Hornbill Abundance in Unlogged Forest, Selectively Logged Forest and a Forest Plantation in Arunchal Pradesh, India. Oryx, 32(4), 285-294.

[5] Datta, A. (2009). Observations on Rufous-necked Hornbill Aceros nipalensis and Austen's Brown Anorrhinus austeni Hornbills in Arunchal Pradesh: Natural History, Conservation Status, and Threats. Indian BIRDS, 5(4), 108-117.

[6] Datta, A., \& Rawat, G. S. (2003). Foraging Patterns of Sympatric Hornbills During the Non-breeding Season in Arunachal Pradesh, Northeast India. Biotropica, 35(2), 208-218

[7] DoFPS. (2018). Forest Facts and Figures 2018. Thimphu, Bhutan: Department of Forest and Park Services, Ministry of Agriculture and Forest, Royal Government of Bhutan.

[8] Dorji, S. (2013). Habitat Use and Conservation Status of Rufous-necked Hornbill in Jigme Singye Wangchuck National Park of Bhutan (Unpublished B.Sc. Thesis).

[9] eBird. (2020). Rufous-necked Hornbill, Bhutan. Retrieved 2020, from eBird: www.ebird.org

[10] Grimmett, R., Inskipp, C., Inskipp, T., \& Sherub. (2019). Birds of Bhutan and the Eastern Himalayas. New Delhi: Bloomsbury Publishing India Pvt. Ltd.

[11] iNaturalist. (2020). Rufous-necked Hornbill, Bhutan. Retrieved 2020, from iNaturalist: www.inaturalist.org

[12] Inskipp, C., Inskipp, T., \& Grimmett, R. (1999). Birds of Bhutan: Timeless Field Guide. London: Christopher Helm Ltd.

[13] Jinamoy, S. (2013). Estimating Density of Rufousnecked Hornbill (Aceros nipalensis) Using Distance
Sampling in Thung Yai Naresuan (East) Wildlife Sanctuary. Journal of Wildlife in Thailand, 20(1).

[14] Kannan, R., \& James, D. A. (1999). Fruiting Phenology and the Conservation of the Great Hornbil (Buceros bicornis) in the Western Ghats of Southern Indial. Biotropica, 31(1), 167-177.

[15] Mudappa, D., \& Raman, T. (2009). A Conservation Status Survey of Hornbills (Bucerotidae) in the Western Ghats, India. Indian BIRDS, 5(4), 90-102.

[16] NBC. (2019). Biodiversity Statistics of Bhutan 2017. Thimphu, Bhutan: National Biodiversity of Bhutan, Minister of Agriculture and Forest, Serbithang.

[17] NBSAP. (2014). National Biodiversity Strategies and Action Plan. Thimphu, Bhutan: National Biodiversity Centre, Serbithang.

[18] Pandit, M. K., \& Grumbine, R. E. (2012). Potential Effects of Ongoing and Proposed Hydropower Development on Terrestial Biological Diversity in the Indian Himalaya. Conservation Biology, 26(6), 10611071.

[19] Pandit, M. K., Manish, K., \& Koh, L. P. (2014). Dancing on the Roof of the World: Ecological Transformation of the Himalaya Landscape. BioScience, 64(11), 980-992.

[20] Poonswad, M. K., Kemp, A., \& Strange, M. (2013). Hornbills of the World: A photographic Guide. Singapore: Draco Publishing \& Distribution Pvt. Ltd.

[21] Poonswad, P. (1998). The Asian Hornbills: Ecology and Conservation. Thai Studies in Biodiversity(2), 1336.

[22] Poonswad, P., \& Kemp, A. (1993). Manual to the Conservation of Asian Hornbills. Bangkok: Sirvatana Interprint Co. Ltd.

[23] RGoB. (1995). Forest and Nature Conservation Act of Bhutan, 1995. Thimphu: Royal Government of Bhutan.

[24] Sadadev, B. M., Dhami, B., Bista, S., Neupane, B., Thapa, N., Rawat, Y. B., et al. (2020). Exploring Distributional Evidences and Threats to Initiate Conservation of Great Hornbill (Buceros bicornis) in Nepal. Archives of Agriculture Research and Technology, 1(3), 1011-1013.

[25] Sherub, K., \& Singh, A. P. (2020). Notes on the Food and Feeding Habits of Rufous-necked Hornbill Aceros nipalensis in Zhemgang Disstrict, Bhutan. Journal of Bombay Natural History Society, 117, 50-53.

[26] Sherub, K., \& Tshering, S. (2019). Rapid Assessment of Two Sympatric Hornbill Species Populations and Their Nesting Behavior in Zhemgang District, Bhutan. BirdingAsia, 31, 54-58.

[27] Shukla, U., Naniwadekar, R., \& Datta, A. (2016). Abundance Estimates of the Rufous-necked Hornbill, and Characterisation of a Montane Subtropical Forest in the Eastern Himalaya. Indian Birds, 12(4), 128-134.

[28] Tella, R. D., \& MacCulloch, R. (2008). Gross National Happiness as an Answer to the Easterlin Parodox? Journal of Development Economics, 86(1), 22-42.

[29] Thongsikem, V., Poonswad, P., \& Kemp, A. (2014). Predictive Distribution Modelling for Rufous-necked Hornbill Aceros nipalensis (Hodgson, 1829) in the Core of the Western Forest Complex, Thailand. Raffles Bulletin of Zoology, 62, 12-20.

\section{Volume 9 Issue 11, November 2020}




\section{International Journal of Science and Research (IJSR) ISSN: 2319-7064 \\ SJIF (2019): 7.583}

[30] Tobgay, S. (2015). The Constitution of Bhutan: Principles and Philosophies. Thimphu, Bhutan: Bhutan National Legal Studies.

[31] UWICER. (2017). Hornbills: Connecting Environment, Economy and Culture in Bhutan. Lamai
Goempa, Bumthang: Department of Forest and Park Services, Ministry of Agriculture and Forests, Royal Government of Bhutan.

Appendix 1: List of species of fruitson the diet of Rufous-necked Hornbill in Bhutan (all the common languages are from Bhutan)

\begin{tabular}{|c|c|c|c|c|c|c|}
\hline S.No. & Family & Species & Common Name & Habit & $\begin{array}{l}\text { Fruit } \\
\text { Type }\end{array}$ & \begin{tabular}{|l|} 
IUCN \\
Status \\
\end{tabular} \\
\hline 1 & Alangiaceae & Alangiumalpinum & Domseng (Kheng), Galasune (Nepali) & Small tree & Drupe & LC \\
\hline 2 & \multirow{4}{*}{ Anacardiaceae } & Spondiaspinnata & Amaroo (Nepali), Amber shing (Sha) & Deciduous tree & Drupe & $\mathrm{LC}$ \\
\hline 3 & & Drimycarpusracemosus & Kadarmey (Kheng), KhakBalaiyo (Nepali) & Evergreen tree & Drupe & $\mathrm{LC}$ \\
\hline 4 & & Mangiferasylvatica & ChucheAnp (Nepali), Shutale (Kheng) & Evergreen tree & Drupe & $\mathrm{LC}$ \\
\hline 5 & & Choerospondiasaxillaris & $\begin{array}{c}\text { Thrungchungshing (Sha), Lapsi (Nepali), Klunmachi } \\
\text { (Kheng) }\end{array}$ & Evergreen tree & Drupe & $\mathrm{LC}$ \\
\hline 6 & Boraginaceae & Ehretia sp. & Jagpaseng (Kheng) & Tree & Berry & $\mathrm{LC}$ \\
\hline 7 & Burseraceae & Canariumstrictum & $\begin{array}{c}\text { Poikar (Dzongkha), Poikarshing (Sha), Gokuldhup } \\
\text { (Nepali) }\end{array}$ & Evergreen tree & Drupe & $\mathrm{LC}$ \\
\hline 8 & Elaeocarpaceae & Elaeocarpuslanceifolius & $\begin{array}{c}\text { Khashakokpa (Kheng/ Kurtoed), Khashatarka(Tsamang), } \\
\text { GashaThungshing (Sha), Bhadrasey (Nepali) }\end{array}$ & Evergreen tree & Drupe & $\mathrm{LC}$ \\
\hline 9 & \multirow{10}{*}{ Lauraceae } & Perseaodoratissima & Shjaguli (Kurtoed) & Small tree & Drupe & LC \\
\hline 10 & & Alseodaphne sp. & Bragshing (Saling) & Evergreen tree & Drupe & $\mathrm{LC}$ \\
\hline 11 & & Persea sp. & Serkala (Kheng), Guliser (Saling) & \begin{tabular}{|l|} 
Evergreen tree \\
\end{tabular} & Drupe & $\mathrm{LC}$ \\
\hline 12 & & Phoebe sp. & Chogsengma (Kheng) & Evergreen tree & Drupe & $\mathrm{LC}$ \\
\hline 13 & & Parasassafrasconfertiflora & Shingmar/ Singsii (Sha), Kalobori (Nepali) & Small tree & Drupe & LC \\
\hline 14 & & Cinnamomumbejolghota & Throkthrrokla/ Zapale (Kheng) & Evergreen tree & Drupe & $\mathrm{LC}$ \\
\hline 15 & & Cinnamomumglaucescens & $\begin{array}{c}\text { Kipchushing (Dzongkha), Kawla/Malagiri (Nepali), } \\
\text { Wamchagpa (Kheng) }\end{array}$ & Shrub & Drupe & DD \\
\hline 16 & & Beilschmiediavillosa & Krupti (KhengBroksar) & Tree & Drupe & DD \\
\hline 17 & & Beilschmiediaroxburghiana & ThruloTarsing (Nepali), Praguli/ Brangkhala (Kheng) & Evergreen & Drupe & DD \\
\hline 18 & & Beilscmediaclarkei & SanuTarsing (Nepali) Brangkhala (Kheng) & Evergreen tree & Drupe & DD \\
\hline 19 & Flacourtiaceae & Caseariaglomerata & Phanglaseng (kheng), Barkaunle (Nepali) & Shrub & Capsule & $\mathrm{LC}$ \\
\hline 20 & \multirow{2}{*}{ Meliaceae } & Aglaiaedulis & Yamphaisey (Sha) & Deciduous tree & Capsule & $\mathrm{LC}$ \\
\hline 21 & & Aglaiacucullata & Khwelaiseng (Kheng) & Evergreen tree & capsule & LC \\
\hline 22 & \multirow{2}{*}{ Moraceae } & Macluracochinchinensis & MaidalKanra (Nepali) & $\begin{array}{l}\text { Climbing } \\
\text { Shrub }\end{array}$ & Berry & $\mathrm{NE}$ \\
\hline 23 & & Ficusauriculata & Chongma (Sha), Nebaro (Nepali), Khomdhang (Kheng) & Tree & Syconia & NE \\
\hline 24 & Proteaceae & Helicianilgirica & Potorshing (Sha), Bandre (Nepali) & Small tree & Drupe & $\mathrm{LC}$ \\
\hline 25 & Santalaceae & Pyrulariaedulis & Amphi (Nepali), Tan li (Chinese) & Small tree & Drupe & LC \\
\hline 26 & \multirow{2}{*}{ Vitaceae } & Cyphostemmaauriculatum & Zezeymairuu (Kheng) & $\begin{array}{l}\text { Climbing } \\
\text { shrub }\end{array}$ & Berry & - \\
\hline 27 & & Tetrastigmaleucostaphylum & Crenpashui (Kheng), Bherseri (Nepali) & $\begin{array}{l}\text { Large climbing } \\
\text { shrub }\end{array}$ & Berry & $\mathrm{LC}$ \\
\hline 28 & Solanaceae & Cyphomandrabetacea & ShingLambendha (Kurtoed/ Kheng) & Small tree & Berry & NE \\
\hline 29 & \multirow[b]{2}{*}{ Rosaceae } & Docyniaindica & Tong (Dzongkha), Thungkakpa (Sha), Mel (Nepali) & Deciduous tree & Pome & $\mathrm{LC}$ \\
\hline 30 & & Fragarianubicola & Strawberry, Marib (Kheng) & $\begin{array}{c}\text { Stoloni-ferous } \\
\text { herb }\end{array}$ & Berry & $\mathrm{LC}$ \\
\hline 31 & Phyllanthaceae & Emblicaofficinalis & Churu (Dzongkha) Kudth (Kheng), Amala (Nepali) & $\begin{array}{l}\text { Deciduous } \\
\text { shrub }\end{array}$ & Capsule & $\mathrm{LC}$ \\
\hline 32 & Fagaceae & Castanopsis or Lithocarpus & Shakhoi (Kheng) & - & Acorn & - \\
\hline 33 & Magnoliaceae & Michelia $s p$ & Kharshing (Kheng) & Evergreen tree & - & $\mathrm{LC}$ \\
\hline 34 & $\begin{array}{l}\text { Unknown } \\
\text { species }\end{array}$ & Unknown sp. & Nyeclodth (Kheng) & Tree & Drupe & - \\
\hline
\end{tabular}

Appendix 2: List of species of animals on the diet of Rufous-necked Hornbill in Bhutan (all the common languages are from Bhutan)

\begin{tabular}{|c|c|}
\hline Vertebrate & Invertebrate \\
\hline Animal & Animal \\
\hline Lizards & Caterpillar \\
\hline Rats & Crab \\
\hline Squirrels & Snails \\
\hline Frog & Bettles \\
\hline Snake & Cikada \\
\hline Bird Chick & Wild bees \\
\hline & Chirpine Caterpillar \\
\hline
\end{tabular}

\section{Volume 9 Issue 11, November 2020} www.ijsr.net 